\title{
Particulate organic carbon export in the upper twilight zone during the decline of the spring bloom
}

\author{
Julien Pommier ${ }^{1}$, Christine Michel $^{2, *}$, Michel Gosselin ${ }^{1}$ \\ ${ }^{1}$ Institut des sciences de la mer (ISMER), Université du Québec à Rimouski, 310 allée des Ursulines, Rimouski, \\ Québec G5L 3A1, Canada \\ ${ }^{2}$ Freshwater Institute, Fisheries and Oceans Canada, 501 University Crescent, Winnipeg, Manitoba R3T 2N6, Canada
}

\begin{abstract}
The variability of particulate organic carbon (POC) sinking flux and its relationship to primary production were investigated in the upper twilight zone of the northwest Atlantic Ocean on 4 occasions during a Lagrangian study of the decline of a spring diatom bloom and its transition towards post-bloom conditions. POC sinking fluxes below the euphotic zone (50 to $75 \mathrm{~m}$ depth) decreased from (mean $\pm \mathrm{SD}$ ) $674 \pm 105$ to $281 \pm 17 \mathrm{mg} \mathrm{C} \mathrm{m}^{-2} \mathrm{~d}^{-1}$ throughout the senescence of the bloom and further decreased to $197 \pm 2 \mathrm{mg} \mathrm{C} \mathrm{m}^{-2} \mathrm{~d}^{-1}$ under post-bloom conditions. POC sinking fluxes below the euphotic zone were positively correlated to the production of large phytoplankton cells $(\geq 5 \mu \mathrm{m}$ ) throughout the study period, highlighting the importance of the size structure of primary producers in shaping the export of POC from the euphotic zone. In contrast, POC sinking fluxes at $150 \mathrm{~m}$ depth showed little variation throughout the study period. Analysis of the vertical profiles of POC sinking flux revealed an increase in POC transfer efficiency from 50 to $150 \mathrm{~m}$ depth due to a decrease in POC recycling within the upper twilight zone throughout the decline of the bloom. Moreover, POC recycling within the upper twilight zone was positively correlated with POC sinking fluxes below the euphotic zone throughout the study period, suggesting that recycling processes in the upper twilight zone respond rapidly and proportionally to the export of POC from the euphotic zone. It is hypothesized that the concomitant decreases in POC sinking fluxes below the euphotic zone and in POC recycling within the upper twilight zone compensated each other and could explain the fairly constant POC sinking fluxes at $150 \mathrm{~m}$ depth that were observed throughout the study period. Our results shed light on the importance of short-term variability in organic matter recycling within the upper twilight zone for the efficiency of POC export to depth.
\end{abstract}

KEY WORDS: POC sinking fluxes - Primary production $\cdot$ Twilight zone $\cdot$ Sediment trap $\cdot$ Fecal pellets $\cdot$ Spring bloom $\cdot$ Northwest Atlantic Ocean

\section{INTRODUCTION}

Over the last few decades, much effort has been put into understanding the relationship between primary production and carbon export to depth in the world ocean. This interest was largely motivated by the need to predict the efficiency of the biological carbon pump (Volk \& Hoffert 1985) in sequestering carbon dioxide in the deep ocean and possibly mitigating the increase in anthropogenic emissions of this climate-relevant greenhouse gas in the context of a globally warming climate.
Most of the contemporary knowledge regarding the coupling between primary production and carbon export to depth is derived from time-series particle interceptor traps moored in the deep ocean that measure particle fluxes at weekly to monthly intervals over periods of several months to more than a year (Honjo 1996). These deep-ocean mooring arrays have proved to be very useful tools in relating the magnitude and temporal patterns of deep carbon fluxes with the seasonality of phytoplankton production (Wefer 1989) and the size structure of primary producers (Boyd \& Newton 1999). Results from long-term particle interceptor 
traps have also served as the basis for developing algorithms that seek to model the export of particulate organic carbon (POC) to depth (Bishop 1989).

Nevertheless, predictions of deep-sea carbon export from existing algorithms are still subject to uncertainties. These uncertainties are largely attributed to a lack of knowledge on early processes affecting the flux of particles in the twilight zone (i.e. at depths between the base of the euphotic zone $\left[\mathrm{Z}_{\text {eu }}\right]$ and $\sim 1000 \mathrm{~m}$; Buesseler et al. 2007b). The twilight zone, where about $90 \%$ of the exported material is thought to be mineralized, is believed to play a critical role in the transfer of biogenic carbon from the ocean surface to the deep ocean (Angel 1989, Tréguer et al. 2003). While we know from particle interceptor trap data that POC fluxes decrease rapidly with depth within the twilight zone, we have little knowledge on the processes responsible for this mineralization pattern (Ducklow et al. 2001). It is believed that the strength and variability of processes affecting the transformation of particulate material during its sinking strongly influence the coupling between primary and export production and determine the efficiency of particle export to depth over short spatial and temporal scales (Wassmann 1998). It is also recognized that deep POC fluxes could be predicted with greater reliability if the processes affecting the early export of organic material from the productive layer were better understood (Boyd \& Newton 1995).

In temperate and subpolar latitudes of the North Atlantic Ocean, the spring phytoplankton bloom is a major biogeochemical event contributing significantly to the sinking export of particles to the deep ocean (Honjo 1996). In that region of the world ocean, temporal uncoupling between phytoplankton growth and zooplankton grazing can result in a massive sedimentation of organic material at the end of the spring bloom (Parsons \& Lalli 1988, Honjo \& Manganini 1993). The decline of the spring bloom is thus of particular interest for the investigation of the short-term variability in the coupling between primary production and early export processes of particulate organic material. However, there is a lack of information on the sinking flux of organic carbon and its coupling with primary production during that particular stage of the spring bloom at temperate latitudes in the North Atlantic Ocean. Moreover, except for the Western North Atlantic Bloom Experiment $\left(40^{\circ} \mathrm{N}, 47^{\circ} \mathrm{W}\right.$ and $45^{\circ} \mathrm{N}, 41^{\circ} \mathrm{W}$; Harrison et al. 1993), there is a lack of information on the sinking flux of organic carbon in the temperate western North Atlantic Ocean, as most of the particle flux data in the North Atlantic have been collected in the eastern part of this ocean basin (Antia et al. 2001). Finally, to our knowledge, there is no detailed information about POC sinking fluxes in the twilight zone of the temperate North Atlantic Ocean.

Within this framework, our study aimed to (1) characterize the sinking flux of $\mathrm{POC}$ in the upper twilight zone (i.e. from the base of $Z_{\text {eu }}$ down to $150 \mathrm{~m}$ ) during the declining phase of the spring bloom in the temperate northwest Atlantic Ocean, (2) investigate the coupling between the activity and size structure of primary producers in $Z_{\text {eu }}$ and POC export in the upper twilight zone, and (3) assess the processes affecting the transformation of the sinking material within the upper twilight zone. This study is part of the Canadian Surface Ocean-Lower Atmosphere Study (C-SOLAS) which aims to quantify the impact of the senescence of the North Atlantic spring bloom on the production and ventilation to the atmosphere of climatically active trace gases.

\section{MATERIALS AND METHODS}

Sampling. Sampling was carried out aboard the Canadian Coast Guard Ship (CCGS) 'Hudson' off the Scotian Shelf at Stn L (water depth ca. 3500 m; Fig. 1) as part of a Lagrangian survey of the decline of the spring bloom in the northwest Atlantic Ocean (Forget et al. 2007a). A water mass within which a phytoplankton bloom had developed was sampled from 25 April (Day 1) to 1 May 2003 (Day 7). The water mass under investigation was tracked using a CAST ARGOS drifter (Seimac Smart CAT PTT/GPS transmitter) equipped with a $15 \mathrm{~m}$ long Holey Sock tubular drogue centered at $15 \mathrm{~m}$ in the water column. On 14 May (Day 20), the station occupied on Day 1 was revisited and samples were collected in order to study the potential biogeochemical changes in $Z_{\text {eu }}$ that could have occurred at that sampling location after the decline of the spring bloom and the potential impact of these changes on the sinking fluxes of biogenic material. Concomitant investigations of primary production and particle sinking fluxes were conducted on 26 April (Day 2), 28 April (Day 4), 30 April (Day 6) and 14 May (Day 20).

Analyses. Primary production rates were measured at 7 depths within $Z_{\text {eu }}(100,50,30,15,5,1$ and $0.2 \%$ of surface photosynthetically active radiation [PAR]) using the ${ }^{14} \mathrm{C}$-uptake method (Knap et al. 1996, Gosselin et al. 1997) with on-deck in situ simulated incubations from sunrise to sunset. Primary production rates were integrated over the $Z_{\text {eu }}$ depth using trapezoidal integration. The production rates of small $\left(\mathrm{P}_{\mathrm{S}}\right.$ i 0.7 to $5 \mu \mathrm{m})$ and large $\left(\mathrm{P}_{\mathrm{Li}} \geq 5 \mu \mathrm{m}\right)$ phytoplankton cells were considered. Detailed information about primary production measurements can be found in Pommier (2007). 


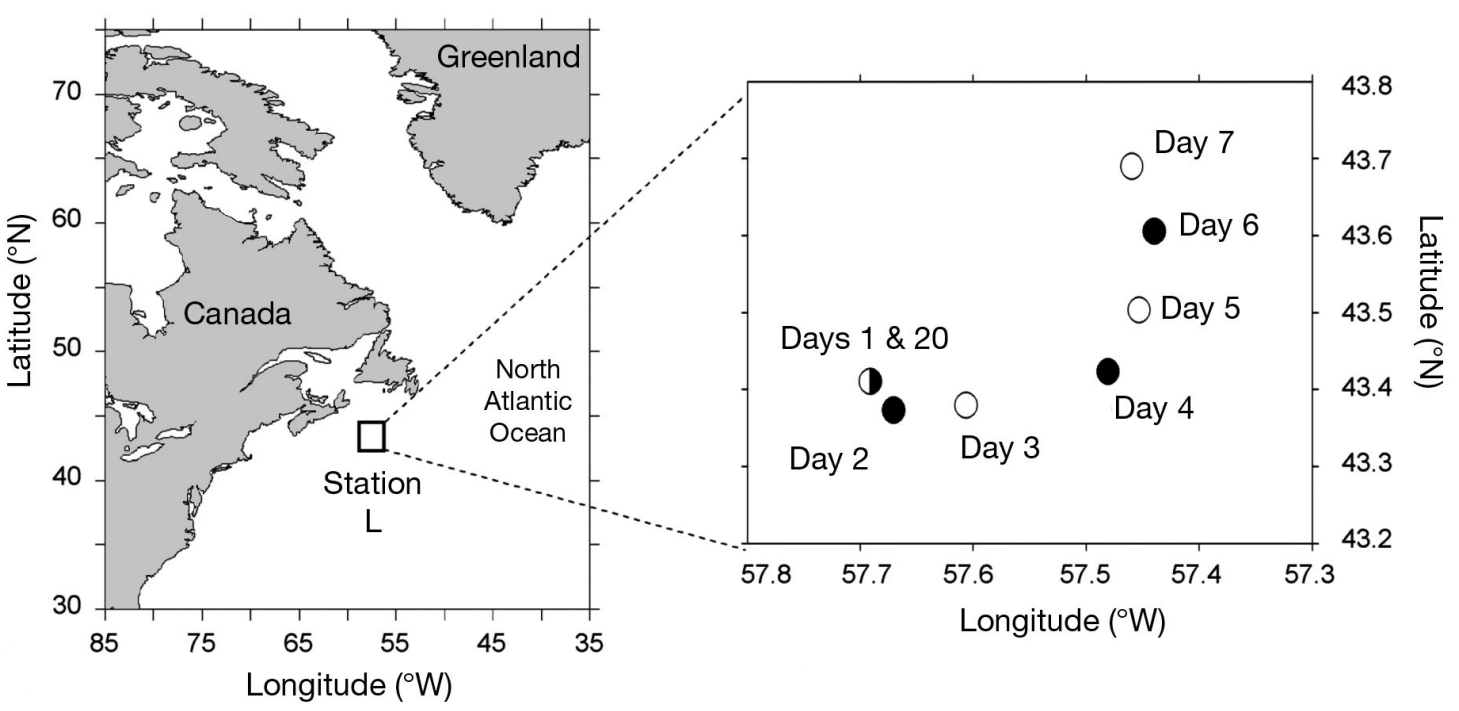

Fig. 1. Location of the drifting buoy from Day 1 (25 April) to Day 7 (1 May). On Day 20 (14 May), the ship went back to the latitude/longitude position occupied on Day 1. Sampling days during which concomitant measurements of primary production and particulate organic material sinking fluxes were made (

Free-drifting particle interceptor traps were deployed for periods of $24 \mathrm{~h}$ (Table 1). The traps, which were PVC cylinders with an internal diameter of $10 \mathrm{~cm}$ and an aspect ratio (height:diameter) of 7 , were deployed at 5 depths $(50,75,100,125$ and $150 \mathrm{~m})$ below both the surface mixed layer and the base of $Z_{\mathrm{eu}}$ (except for the trap deployed at $50 \mathrm{~m}$ on Day 20; Table 1). In the present study, we focus on the sinking fluxes of organic material below the base of $\mathrm{Z}_{\mathrm{eu}}$ and at $150 \mathrm{~m}$. The vertical structure of the water column, which was characterized using a CTD probe (Sea-Bird SBE 9), revealed that the deepest trap was located within the permanent thermocline (Fig. 2). For each depth, 2 traps were installed on the mooring line and centered on the sampling depth. Trap deployment and handling were performed according to Knap et al. (1996) and recommendations from Gardner (2000). The free-drifting particle interceptor traps were surface-tethered with a series of 5 small buoys so as to dampen wave action and minimize vertical motion on the trap line. Before deployment, the traps were filled with deep seawater that had been pre-filtered through a $0.22 \mu \mathrm{m}$ polyvinyliden fluoride (PVDF) Millipore Durapore membrane and salt was added (to increase salinity by 5) to create a dense layer within the traps. No poison or preservative was added before deployment. Upon recovery, the traps were covered with a tight lid and placed vertically in a dark and cool room for $8 \mathrm{~h}$. After that sedimentation period, the supernatant was carefully removed and the bottom volume of the trap (900 to $1000 \mathrm{ml}$ ), which was pre-screened using a $425 \mu \mathrm{m}$ Nitex mesh to remove large swimmers, was kept in acid-washed Nalgene bottles for subsequent analyses.

Duplicate subsamples for the determination of chlorophyll a (chl a) and pheopigments were filtered onto Whatman GF/F filters and the concentrations of these pigments were measured aboard the ship using a

Table 1. Characteristics of the free-drifting particle interceptor trap moorings and of the upper water column. The depths of the euphotic zone $\left(\mathrm{Z}_{\mathrm{eu}}\right)$ and of the surface mixed layer $\left(\mathrm{Z}_{\text {mix }}\right)$ are from Pommier $(2007)$

\begin{tabular}{|c|c|c|c|c|c|c|c|c|c|}
\hline \multirow[t]{2}{*}{ Day } & \multirow{2}{*}{$\begin{array}{l}\text { Date } \\
(2003)\end{array}$} & \multirow{2}{*}{$\begin{array}{l}\text { Duration } \\
\text { (d) }\end{array}$} & \multicolumn{2}{|c|}{ — Deployment — } & \multicolumn{2}{|c|}{$\longrightarrow$ Recovery -} & \multirow{2}{*}{$\begin{array}{c}\text { Distance } \\
\text { traveled } \\
(\mathrm{km})\end{array}$} & \multirow{2}{*}{$\begin{array}{l}Z_{\text {eu }} \\
(\mathrm{m})\end{array}$} & \multirow{2}{*}{$\begin{array}{l}Z_{\text {mix }} \\
(\mathrm{m})\end{array}$} \\
\hline & & & $\begin{array}{l}\text { Latitude } \\
\left({ }^{\circ} \mathrm{N}\right)\end{array}$ & $\begin{array}{l}\text { Longitude } \\
\left({ }^{\circ} \mathrm{W}\right)\end{array}$ & $\begin{array}{c}\text { Latitude } \\
\left({ }^{\circ} \mathrm{N}\right)\end{array}$ & $\begin{array}{l}\text { Longitude } \\
\left({ }^{\circ} \mathrm{W}\right)\end{array}$ & & & \\
\hline 2 & 26 April & 0.91 & $43^{\circ} 21.4$ & $57^{\circ} 37.9$ & $43^{\circ} 21.7$ & $57^{\circ} 34.1$ & 4.3 & 43 & 12 \\
\hline 4 & 28 April & 1.06 & $43^{\circ} 24.6$ & $57^{\circ} 28.9$ & $43^{\circ} 28.9$ & $57^{\circ} 28.1$ & 7.5 & 45 & 23 \\
\hline 6 & 30 April & 0.88 & $43^{\circ} 37.1$ & $57^{\circ} 25.8$ & $43^{\circ} 40.3$ & $57^{\circ} 28.5$ & 6.9 & 50 & 26 \\
\hline 20 & 14 May & 0.99 & $43^{\circ} 21.9$ & $57^{\circ} 42.6$ & $43^{\circ} 20.4$ & $57^{\circ} 41.6$ & 2.4 & 60 & 6 \\
\hline
\end{tabular}




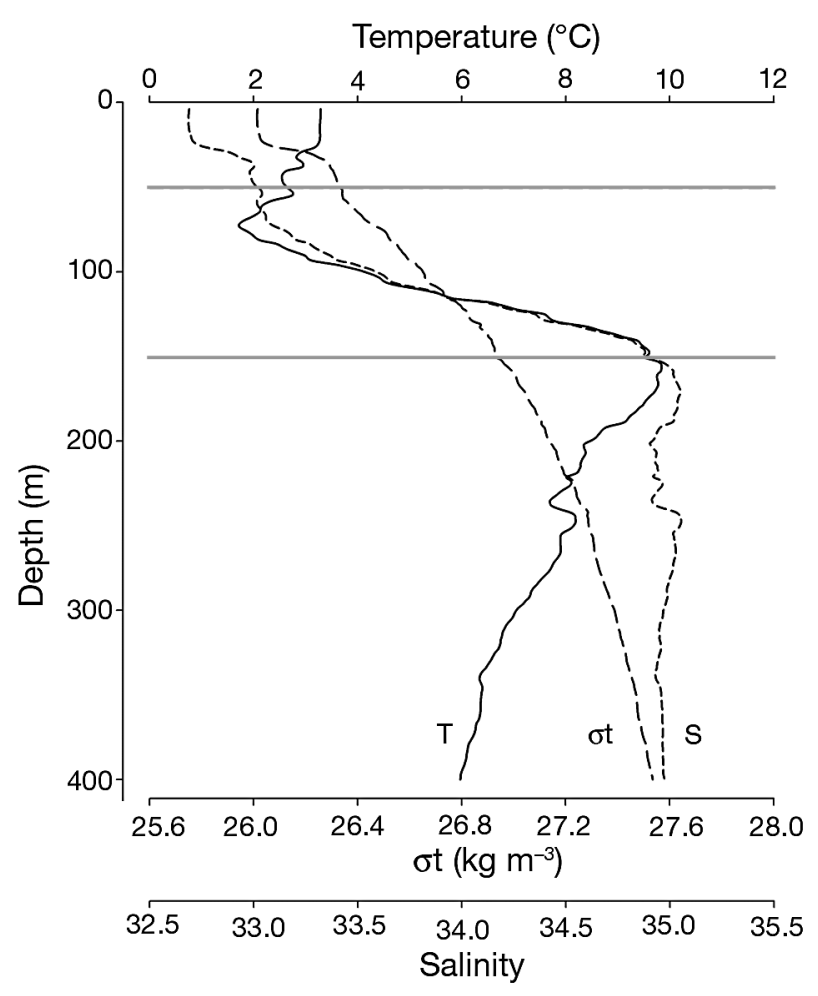

Fig. 2. Vertical profiles of temperature $(\mathrm{T},-)$, salinity $(\mathrm{S},--)$ and sigma-t $(\sigma \mathrm{t},--)$ in the upper $400 \mathrm{~m}$ of the water column on Day 4 (28 April). Horizontal grey lines: depths of the shallowest $(50 \mathrm{~m})$ and deepest $(150 \mathrm{~m})$ particle interceptor traps

Turner Designs 10-005R fluorometer after a $24 \mathrm{~h}$ extraction in $90 \%$ acetone at $4^{\circ} \mathrm{C}$ in the dark (Parsons et al. 1984). POC concentrations were determined in duplicate with a Perkin-Elmer Model 2400 CHN Analyzer from samples concentrated on pre-combusted $\left(450^{\circ} \mathrm{C}\right.$ for $\left.5 \mathrm{~h}\right)$ Whatman GF/F filters and kept frozen $\left(-20^{\circ} \mathrm{C}\right)$ in Petri dishes before analysis in the laboratory. In order to assess the solubilization of particulate organic material during the deployment period (Kähler \& Bauerfeind 2001), dissolved organic carbon (DOC) was measured in the traps before and after deployment using a TOC-5000A Shimadzu analyzer following the procedure explained in Roux et al. (2002). The export ratio (e-ratio, i.e. the ratio of POC sinking flux at a given depth to particulate primary production integrated over the $Z_{\text {eu }}$ depth; dimensionless) was calculated based on primary production measurements performed during the trap deployment period. Phytoplankton cells and zooplankton fecal pellets from the traps were collected and analyzed in order to estimate their contribution to the total POC sinking flux. Phytoplankton cells were fixed and preserved in acidic Lugol's solution (Throndsen 1978) and were identified to the lowest possible taxonomic level using the inverted microscope method (Utermöhl 1931, Lund et al. 1958). For each sample, at least 300 cells were counted from the whole sample. Up to 25 cells were measured per enumerated taxon and their biovolumes calculated using appropriate geometric equations (Hillebrand et al. 1999). An average biovolume per taxon was determined and converted into carbon biomass using factors given in Menden-Deuer \& Lessard (2000). This carbon biomass, combined with the abundance of cells for each taxon, was used to obtain the contribution of each taxon to the POC sinking flux. The number and size of fecal pellets were also determined in subsamples preserved in hexamine-buffered formaldehyde ( $2 \%$ final concentration) using the inverted microscope. Two types of fecal pellets were identified, assuming a prolate spheroid shape for appendicularian feces and a cylindrical shape for calanoid copepod fecal pellets (Urban et al. 1993). The length and width of complete and broken pellets were measured and the total biovolume of each type of pellet was calculated using the appropriate equations. Biovolumes were then converted into carbon biomass using a factor of $0.057 \mathrm{mg} \mathrm{C} \mathrm{mm}{ }^{-3}$ and $0.042 \mathrm{mg} \mathrm{C} \mathrm{mm}^{-3}$ for copepod and appendicularian pellets, respectively (González et al. 1994).

\section{RESULTS}

POC sinking fluxes progressively decreased with depth on all sampling days (Fig. 3). A progressive weakening of the depth-related decrease in POC sinking fluxes was observed from Days 2 to 6, as reflected by the decreasing slopes of the curves of POC sinking

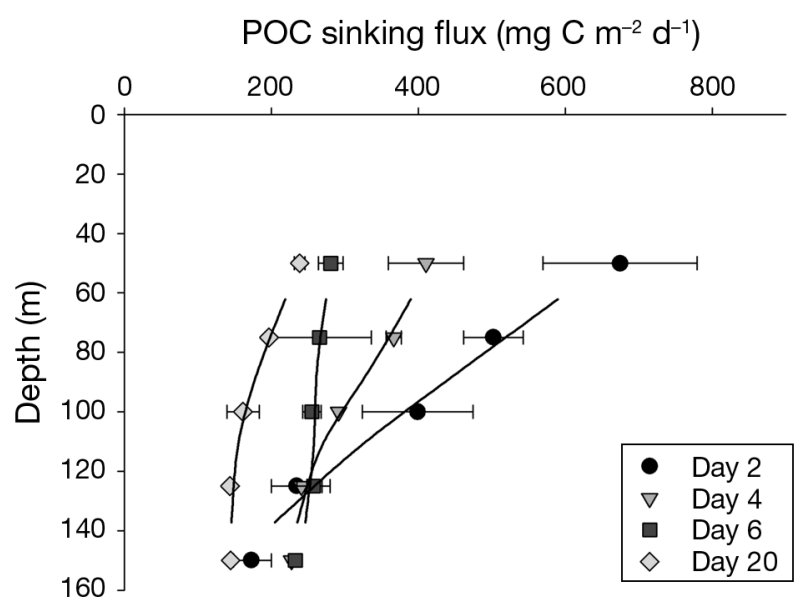

Fig. 3. Temporal changes in the vertical profiles of particulate organic carbon (POC) sinking flux from 50 to $150 \mathrm{~m}$ (mean \pm $\mathrm{SD})$. For each day, the symbols represent the observed data; the curve is a moving average $(n=2)$ 
fluxes with depth (Fig. 3). From Days 2 to 6, particulate primary production decreased $(\mathrm{p}<0.01$; significance was determined using the Wilcoxon signed-ranks test unless otherwise specified) and was dominated by large phytoplankton cells (Fig. 4a). On Day 20, particulate primary production increased compared to the previous sampling day (Day $6 ; \mathrm{p}<0.01$ ) but was dominated by small phytoplankton cells (Fig. 4a). From Days 2 to 6, POC sinking fluxes below $Z_{\text {eu }}$ (i.e. at $50 \mathrm{~m})$ decreased $(\mathrm{p}<0.01$; Fig. $4 \mathrm{~b})$ in pace with the decrease in particulate primary production. On Day 20 , the POC sinking flux below $\mathrm{Z}_{\text {eu }}$ further decreased ( $<<0.01$; Fig. 4b) whereas primary production increased (Fig. 4a) compared to the previous sampling day. The POC sinking fluxes at $150 \mathrm{~m}$ did not vary
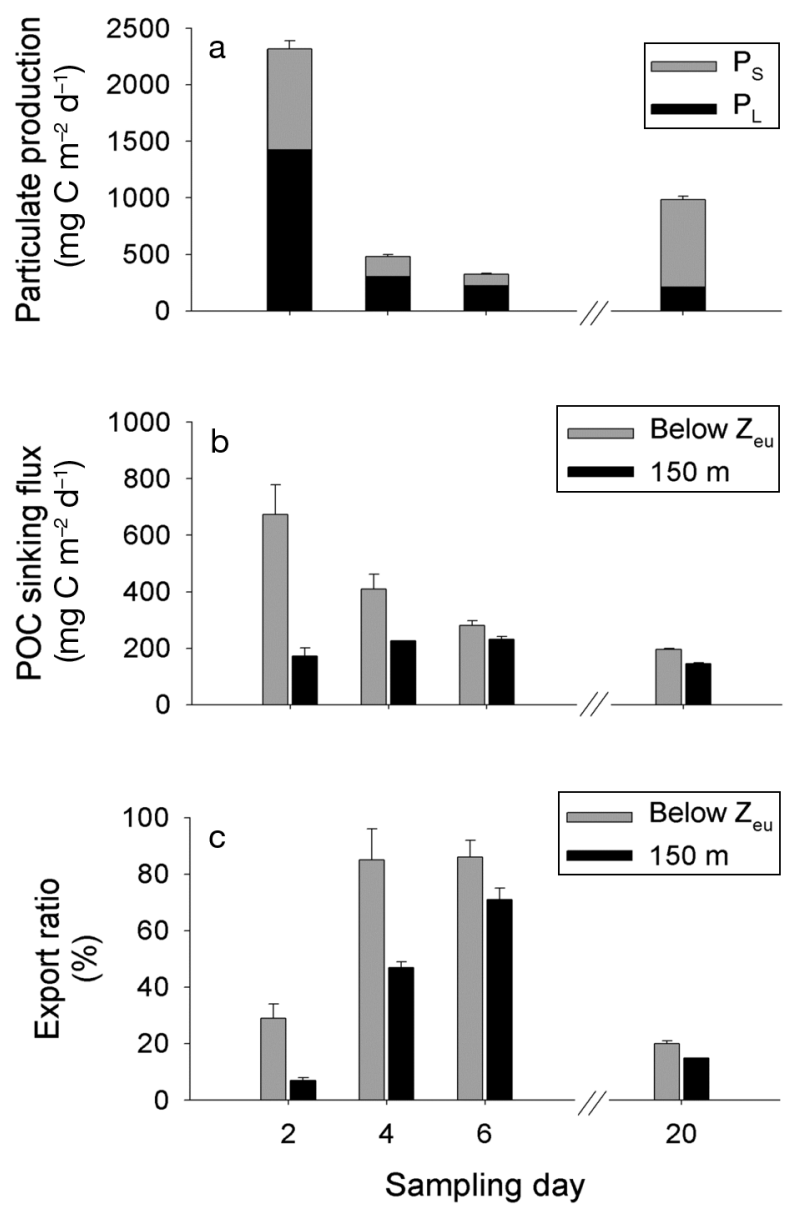

Fig. 4. Temporal changes in (a) size-fractionated particulate primary production integrated over the euphotic zone depth based on our measurements (Pommier 2007); (b) particulate organic carbon (POC) sinking flux below the base of the euphotic zone (below $Z_{\text {eu }}$, i.e. at $50 \mathrm{~m}$ from Days 2 to 6 and at $75 \mathrm{~m}$ on Day 20) and at $150 \mathrm{~m}$; and (c) export ratio below $Z_{\text {eu }}$ and at $150 \mathrm{~m}$. Values are mean + SD. In (a), the production values of small $\left(\mathrm{P}_{\mathrm{S}} ; 0.7\right.$ to $\left.5 \mu \mathrm{m}\right)$ and large $\left(\mathrm{P}_{\mathrm{Li}} \geq 5 \mu \mathrm{m}\right)$ phytoplankton cells are indicated much between the sampling days (Fig. 4b), showing only a slight but significant increase from Days 2 to 4 $(p<0.05)$ and a slight decrease from Days 6 to 20 ( $p<$ 0.01). The e-ratio below $Z_{\text {eu }}$ and at $150 \mathrm{~m}$ (Fig. 4c) increased from Days 2 to 6 and significantly decreased on Day $20(\mathrm{p}<0.01)$. POC sinking fluxes and e-ratios were significantly lower at $150 \mathrm{~m}$ than below $\mathrm{Z}_{\text {eu }}(\mathrm{p}<$ 0.01 ) throughout the study period (Fig. $4 \mathrm{~b}, \mathrm{c})$. Chl $a$ sinking fluxes below $Z_{\text {eu }}$ progressively decreased $(\mathrm{p}<$ 0.01) from Days 2 to 20 (Fig. 5a). At 150 m, chl a sinking fluxes showed little temporal variability, with a small increase observed from Days 2 to 4 and a slight decrease afterwards (Fig. 5a). The chl a sinking fluxes were significantly lower at $150 \mathrm{~m}$ than below $\mathrm{Z}_{\text {eu }}(\mathrm{p}<$ 0.01 ). The percent contribution of chl a to total pigment (chl $a+$ pheopigments) sinking fluxes below $\mathrm{Z}_{\text {eu }}$ was $\geq 52 \%$ from Days 2 to 6 and decreased to $16 \%$ on Day 20 (Fig. 5b). At 150 m, the percent contribution of chl a
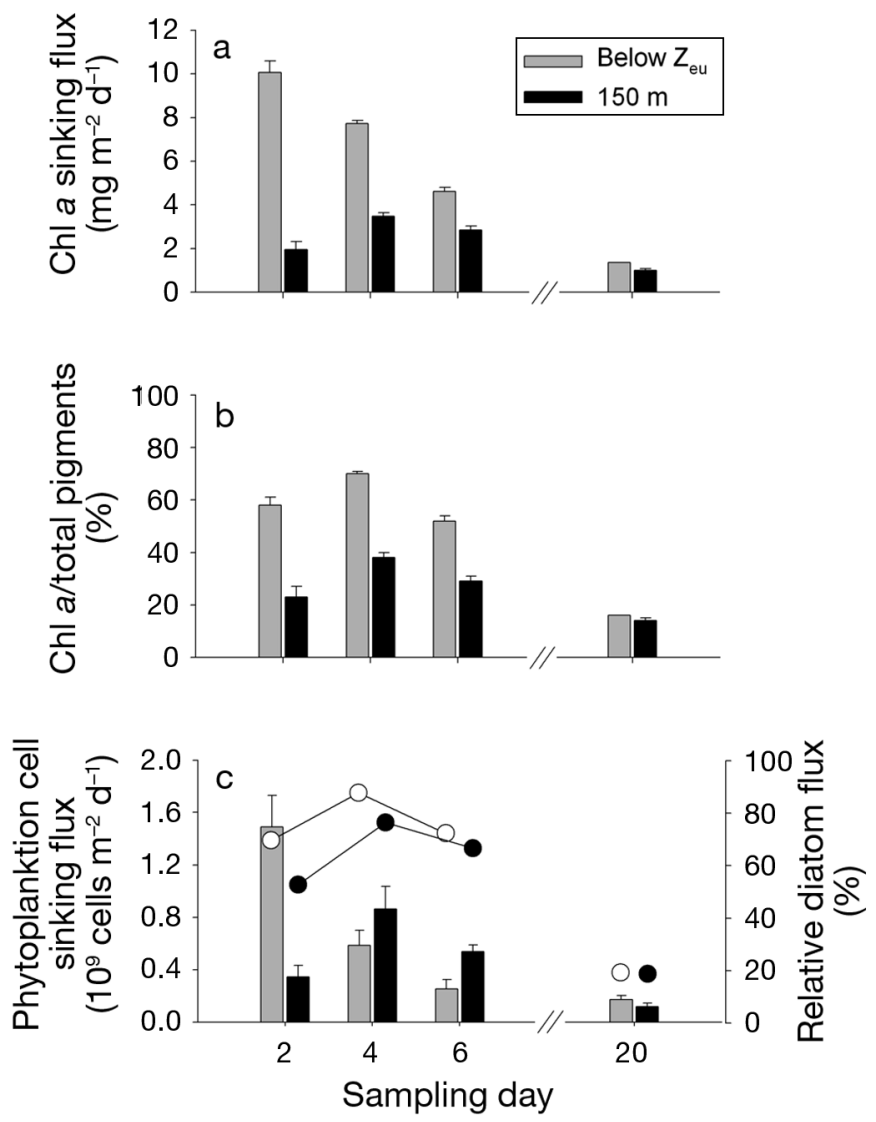

Fig. 5. Temporal changes in (a) chl a sinking fluxes; (b) the ratio of chl $a$ to total pigment (chl $a+$ pheopigments); and (c) the sinking flux of phytoplankton cells below the base of the euphotic zone (below $Z_{\text {eu }}$ i.e. at $50 \mathrm{~m}$ from Days 2 to 6 and at $75 \mathrm{~m}$ on Day 20) and at $150 \mathrm{~m}$. Values are mean + SD. In (c) the percent contribution of diatoms to the total phytoplankton cell sinking fluxes below $\mathrm{Z}_{\text {eu }}(\mathrm{O})$ and at $150 \mathrm{~m}(\bullet)$ are also indicated 
to total pigment fluxes was $<38 \%$; this percent contribution was significantly lower than that below $\mathrm{Z}_{\text {eu }}$ throughout the study period $(p<0.01)$. A reduction in the variations of POC sinking fluxes, e-ratios, chl a sinking fluxes and chl a to total pigment ratios between the 2 sampling depths was observed from Days 2 to 20 (Figs. 4b,c \& 5a,b).

Intact phytoplankton cell sinking fluxes below $Z_{e u}$ progressively decreased throughout the study period (Fig. 5c), whereas phytoplankton cell sinking fluxes at $150 \mathrm{~m}$ increased from Days 2 to 4 and then progressively decreased afterwards (Fig. 5c). On Day 2, intact phytoplankton cell sinking fluxes were significantly lower $(\mathrm{p}<0.01)$ at $150 \mathrm{~m}$ than below $\mathrm{Z}_{\text {eu }}$ whereas on Day 6, phytoplankton cell sinking fluxes at $150 \mathrm{~m}$ were significantly higher than below $\mathrm{Z}_{\text {eu }}$ ( $p<0.05)$. On Days 4 and 20, phytoplankton cell sinking fluxes below $Z_{e u}$ and at $150 \mathrm{~m}$ did not differ significantly ( $\mathrm{p}<0.05$ ). From Days 2 to 6 , intact phytoplankton cell sinking fluxes were dominated by diatoms (of the genera Thalassiosira, Chaetoceros and Fragilariopsis), both below $\mathrm{Z}_{\mathrm{eu}}(\geq 69 \%$ of total cell numbers) and at $150 \mathrm{~m}$ ( $\geq 53 \%$ of total cell numbers) (Fig. 5c). On Day 20, the diatom contribution to intact phytoplankton cell sinking fluxes below $Z_{\text {eu }}$ and at $150 \mathrm{~m}$ were reduced to 18 and $19 \%$, respectively (Fig. 5c). Throughout the study period, the contribution of spores and empty frustules to the total diatom sinking flux (i.e. spores + empty frustules + intact diatom cells) was $\leq 50 \%$ below $Z_{e u}$ and ranged from 49 to $82 \%$ at $150 \mathrm{~m}$.

Sinking carbon fluxes below $\mathrm{Z}_{\text {eu }}$ from intact phytoplankton and fecal pellets showed opposite temporal patterns, with a progressive decrease of the former and an increase of the latter from Days 2 to 20 (Fig. 6a,c). Opposite trends in the temporal changes in the sinking carbon fluxes of phytoplankton and fecal pellets were also observed at $150 \mathrm{~m}$ (Fig. 6a,c). On Day 2, phytoplankton carbon sinking fluxes were significantly higher $(\mathrm{p}<0.01)$ below $\mathrm{Z}_{\text {eu }}$ than at $150 \mathrm{~m}$ (Fig. 6a). From Days 4 to 20, phytoplankton carbon sinking fluxes at $150 \mathrm{~m}$ were not significantly different $(\mathrm{p}<$ 0.05) from those below $Z_{\text {eu }}$ (Fig. 6a). Diatoms dominated the phytoplankton carbon sinking fluxes from Days 2 to 6 (51 to $97 \%$ ), both below $Z_{\text {eu }}$ and at $150 \mathrm{~m}$ (Fig. 6b), while dinoflagellates made a large contribution to the phytoplankton carbon sinking fluxes at both depths (49 to $81 \%$ ) on Day 20 (Fig. 6b). On Day 2, the relative contribution of phytoplankton to the total POC sinking fluxes was lower at $150 \mathrm{~m}(13 \%)$ than below $\mathrm{Z}_{\text {eu }}(22 \%$; Table 2). On Days 4 and 6, the relative contribution of phytoplankton to the total POC sinking fluxes was higher at $150 \mathrm{~m}$ (36 and 26\%, respectively) than below $Z_{\text {eu }}(19$ and $17 \%$, respectively); on Day 20, phytoplankton had about the same contribu-
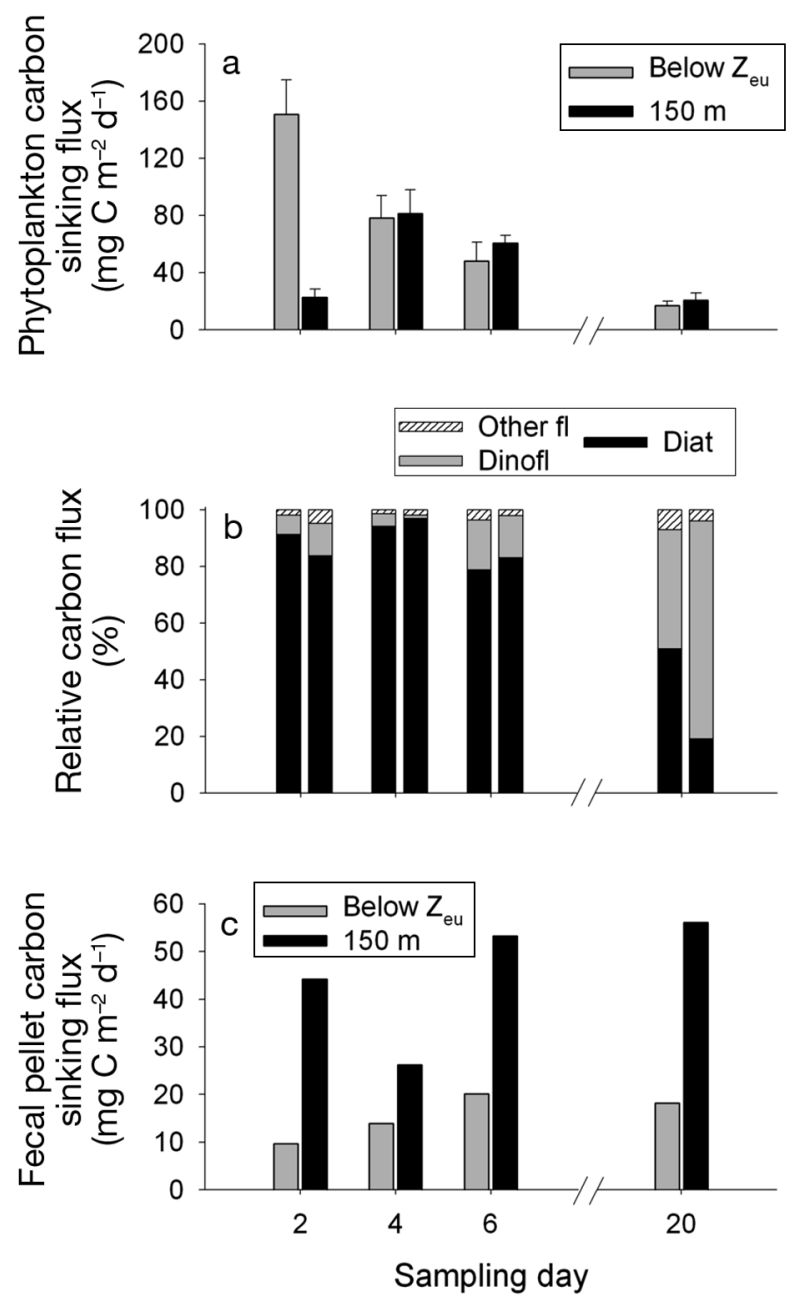

Fig. 6. Temporal changes in (a) intact phytoplankton carbon sinking fluxes; (b) the percent contribution of the 3 major phytoplankton groups (Diat: diatoms, Dinofl: dinoflagellates, Other fl: other flagellates) to total phytoplankton carbon sinking fluxes; and (c) fecal pellet carbon sinking fluxes below the base of the euphotic zone (below $Z_{\text {eu }}$, i.e. at $50 \mathrm{~m}$ from Days 2 to 6 and at $75 \mathrm{~m}$ on Day 20) and at $150 \mathrm{~m}$. In (a) mean values and SDs are presented. For each sampling day in (b) the left and right stacked bars are relative to the flux below $\mathrm{Z}_{\mathrm{eu}}$ and at $150 \mathrm{~m}$, respectively

tion to the total POC sinking fluxes at both depths (9\% below $\mathrm{Z}_{\text {eu }}$ and $14 \%$ at $150 \mathrm{~m}$; Table 2). Fecal pellet carbon fluxes were consistently higher at $150 \mathrm{~m} \mathrm{(26}$ to $56 \mathrm{mg} \mathrm{C} \mathrm{m}^{-2} \mathrm{~d}^{-1}$ ) than below $\mathrm{Z}_{\text {eu }}\left(10\right.$ to $20 \mathrm{mg} \mathrm{C} \mathrm{m}^{-2} \mathrm{~d}^{-1}$ ) throughout the study period (Fig. 6c), as were their percent contributions to the total POC fluxes (12 to $39 \%$ at $150 \mathrm{~m}$ and 1 to $9 \%$ below $Z_{\text {eu }}$ respectively; Table 2). Appendicularian feces slightly dominated the fecal carbon sinking fluxes below $Z_{\text {eu }}$ throughout the study period (52 to $62 \%$ ), except on Day 2 (Table 2), while copepod feces were dominant (53 to $61 \%$ ) at $150 \mathrm{~m}$ (Table 2). 
Table 2. Carbon sinking fluxes of the 3 major phytoplankton groups and of fecal pellet carbon attributed to copepods and appendicularians below the base of the euphotic zone (below $\mathrm{Z}_{\mathrm{eu}}$ ) and at $150 \mathrm{~m}$ throughout the study period. Percent contributions (Contrib.) of total phytoplankton carbon and total fecal pellet carbon to the total particulate organic carbon sinking fluxes are also reported

\begin{tabular}{|c|c|c|c|c|c|c|c|c|}
\hline \multirow[t]{2}{*}{ Day } & \multirow[t]{2}{*}{ Trap depth } & \multirow[b]{2}{*}{ Diatoms } & \multicolumn{2}{|c|}{ Phytoplankton carbon sinking fluxes } & \multirow[b]{2}{*}{$\begin{array}{l}\text { Contrib. } \\
\%\end{array}$} & \multicolumn{3}{|c|}{ — Fecal pellet carbon sinking fluxes } \\
\hline & & & $\begin{array}{c}\text { Dinoflagellates } \\
-\left(\mathrm{mg} \mathrm{C} \mathrm{m}^{-2} \mathrm{~d}\right.\end{array}$ & $\begin{array}{l}\text { Other flagellates } \\
-1)\end{array}$ & & $\underline{\text { Copepo }}$ & $\begin{array}{l}\text { ndicularians } \\
\left.\mathrm{d}^{-1}\right)\end{array}$ & $\begin{array}{c}\text { Contrib. } \\
(\%)\end{array}$ \\
\hline \multirow[t]{2}{*}{2} & Below $\mathrm{Z}_{\mathrm{eu}}$ & 137.6 & 10.3 & 2.8 & 22 & 8.0 & 1.8 & 1 \\
\hline & $150 \mathrm{~m}$ & 19.1 & 2.6 & 1.1 & 13 & 27.2 & 17 & 26 \\
\hline \multirow[t]{2}{*}{4} & Below $\mathrm{Z}_{\mathrm{eu}}$ & 73.9 & 3.5 & 1.0 & 19 & 5.3 & 8.7 & 3 \\
\hline & $150 \mathrm{~m}$ & 78.9 & 1.0 & 1.5 & 36 & 15.8 & 10.4 & 12 \\
\hline \multirow[t]{2}{*}{6} & Below $\mathrm{Z}_{\mathrm{eu}}$ & 38.0 & 8.5 & 1.7 & 17 & 9.2 & 10.9 & 7 \\
\hline & $150 \mathrm{~m}$ & 50.4 & 9.0 & 1.2 & 26 & 28.3 & 24.9 & 23 \\
\hline \multirow[t]{2}{*}{20} & Below $\mathrm{Z}_{\mathrm{eu}}$ & 8.7 & 7.2 & 1.2 & 9 & 8.8 & 9.4 & 9 \\
\hline & $150 \mathrm{~m}$ & 4.0 & 16.1 & 0.8 & 14 & 29.6 & 26.5 & 39 \\
\hline
\end{tabular}

\section{DISCUSSION}

\section{Linking particle sinking fluxes to epipelagic processes}

The present study was part of a $7 \mathrm{~d}$ Lagrangian study of the decline, induced by nitrate limitation, of one of the most productive spring blooms ever reported in the open North Atlantic Ocean and its transition towards post-bloom conditions (Pommier 2007). Throughout the Lagrangian study period (Days 2 to 6), the same water mass containing the bloom patch was effectively tracked (Pommier 2007). When we went back to the initial sampling location 13 d later (Day 20), the presence of warmer and more saline waters in the upper $60 \mathrm{~m}$ of the water column suggests that we sampled a different surface water mass than during the Lagrangian study period (Pommier 2007). However, the sampling station on Day 20 was likely representative of post-bloom conditions in the northwest Atlantic Ocean off the continental Scotian Shelf (Forget et al. 2007b, Pommier 2007). The particle interceptor traps were deployed below the base of $\mathrm{Z}_{\text {eu }}(50$ to $75 \mathrm{~m}$ ) and below the surface mixed layer (6 to $26 \mathrm{~m}$; Table 1 ), so the measured sinking fluxes represented the export of material sinking out of $\mathrm{Z}_{\mathrm{eu}}$. Particle interceptor traps may collect material originating from different areas, so the interpretation of the location and time of origin of the collected particles could be biased (Buesseler et al. 2007a). However, during the Lagrangian study (Days 2 to 6), the free-drifting particle interceptor trap array was deployed and drifted in close proximity to the Lagrangian drifting buoy deployed to track the water mass under investigation. Moreover, the trap array was deployed relatively near $Z_{\text {eu }}$ and the time scale of trap deployments $(24 \mathrm{~h})$ was in phase with that of primary production measurements. Hence, we consider that the particulate primary production rates in $\mathrm{Z}_{\mathrm{eu}}$ and the POC sinking fluxes in the upper twilight zone measured in our study could be related to one another.
The trapping efficiency of our particle interceptor traps was not estimated during the present study. However, the cylindrical shape and aspect ratio (height:diameter $=$ 7) of the traps used in the present study have been found to be effective as free-drifting particle interceptor traps (Baker et al. 1988, Knauer \& Asper 1989). Similar particle interceptor traps and mooring arrays have been used in other studies (Michel et al. 2002, Caron et al. 2004), and comparisons with flux estimates using ${ }^{234} \mathrm{Th}$ have shown close agreement in estimated carbon fluxes (Th-derived carbon flux $=0.68+1.05$ drifting trap flux; $\mathrm{n}=13, \mathrm{r}^{2}=$ $0.89, \mathrm{p}<0.001$; Tremblay et al. 2006). The average increase in DOC concentration within the particle interceptor traps during deployment intervals was $11 \pm 6 \%$ below $Z_{\text {eu }}$ and $10 \pm 5 \%$ at $150 \mathrm{~m}$ throughout the study period, reflecting the potential loss of particulate organic matter (POM) to the dissolved phase (solubilization; Buesseler et al. 2007a) during trap deployments. Solubilization can result from the diffusion of dissolved organic matter from aggregates, bacterial degradation of POM, the activity of swimmers, and physical-chemical processes affecting the dissolution of POM (Buesseler et al. 2007a). However, there is no standardized method for correcting POC sinking fluxes for solubilization and it is most often ignored in short-term upper ocean flux studies (Buesseler et al. 2007a). The small increase in DOC in the particle interceptor traps during our study (ca. 10\%) indicates low solubilization of POM during the period of trap deployments and suggests that our sinking flux measurements might be slightly underestimated.

\section{Coupling between primary production and POC sinking export}

During the decline of the spring bloom, a tight coupling was observed between primary production and POC sinking fluxes below $Z_{\text {eu }}$. Indeed, from Days 2 to 6 , high and decreasing POC sinking fluxes below $\mathrm{Z}_{\text {eu }}$ (from 674 to $281 \mathrm{mg} \mathrm{C} \mathrm{m}^{-2} \mathrm{~d}^{-1}$; Fig. 4b) were consistent 
with high and decreasing integrated production rates in $\mathrm{Z}_{\text {eu }}$ (from 2317 to $326 \mathrm{mg} \mathrm{C} \mathrm{m}^{-2} \mathrm{~d}^{-1}$; Fig. 4a). However, during post-bloom conditions (Day 20), POC sinking fluxes below $Z_{\text {eu }}$ further decreased whereas primary production increased (Fig. 4a,b). On Day 20, small phytoplankton cells (mainly unidentified flagellates $\leq 5 \mu \mathrm{m}$ ) were dominant in terms of primary production (Fig. 4a) and chl a biomass (Pommier 2007). Small cells have low sinking velocities compared to larger cells (Smayda 1970) and are usually considered to be minor contributors to the sinking export of organic material (Legendre \& Le Fèvre 1989), which is in agreement with the low POC sinking fluxes we measured on Day 20. Similarly, high POC sinking fluxes observed from Days 2 to 6 are consistent with the dominance of large cells (mainly centric diatoms) in terms of primary production (Fig. 4a) and chl a biomass (Pommier 2007) during that period. Throughout the study period, POC sinking fluxes below $Z_{\text {eu }}$ were positively correlated to the production rate of large phytoplankton cells (Kendall's $\tau$ coefficient of rank correlation, $\mathrm{p}<0.05)$. These results stress that the size structure of primary producers was more important than the magnitude of primary production in shaping the sinking export of POC from $Z_{\mathrm{eu}}$ throughout the study period. Moreover, POC sinking fluxes below $Z_{\mathrm{eu}}$ were positively correlated with the sinking fluxes of phytoplankton cells (Fig. 5c) and phytoplankton carbon (Fig. 6a) throughout the study period (Kendall's $\tau$ coefficient of rank correlations, $\mathrm{p}<0.05$ ), the 2 latter fluxes being dominated by diatoms (Figs. 5c \& 6b). These results are in agreement with the general understanding that $\mathrm{POC}$ export from $\mathrm{Z}_{\mathrm{eu}}$ is sensitive to ecosystem shifts towards, or away from, the dominance of large cells, particularly diatoms, as part of the phytoplankton assemblage (Boyd \& Newton 1999).

POC sinking fluxes measured at $150 \mathrm{~m}$ compared well with previous values of 160 to $260 \mathrm{mg} \mathrm{C} \mathrm{m}^{-2} \mathrm{~d}^{-1}$ measured at the same depth during springtime in the temperate northwest Atlantic Ocean (Harrison et al. 1993). Interestingly, POC sinking fluxes at $150 \mathrm{~m}$ remained fairly constant throughout the study period despite strong temporal variations in POC sinking fluxes below $Z_{\text {eu }}$ (Fig. $4 \mathrm{~b}$ ) and in both the magnitude of primary production and size structure of the primary producers (Fig. 4a). The same trend was also observed in chl a sinking fluxes at $150 \mathrm{~m}$, which varied little throughout the study period compared to the temporal changes in the chl a sinking fluxes below $Z_{\text {eu }}$ (Fig. 5a) and in the magnitude and size structure of the chl $a$ biomass in $Z_{\text {eu }}$ (Pommier 2007). In contrast with what has been observed below the base of $Z_{\text {eu }}$ our results emphasize the lack of coupling between primary production and POC sinking export at $150 \mathrm{~m}$ throughout the study period. This result is rather unexpected given the premise of organic matter sinking fluxes being positively related to the size structure of pelagic food webs (Legendre \& Le Fèvre 1989, Boyd \& Newton 1999). According to Buesseler (1998), the changes in POC sinking export to depth are more tightly related to changes in the recycling efficiency of pelagic food webs rather than to changes in the intensity and size structure of primary producers. In line with this, the sinking flux of organic matter at $150 \mathrm{~m}$ can be viewed as the result of recycling processes within the twilight zone that affected the exported material from $Z_{\mathrm{eu}}$. Therefore, the fairly constant POC sinking fluxes at $150 \mathrm{~m}$ could result from short-term variability in POC recycling within the twilight zone.

One particular aspect that needs to be considered is the potential temporal lag between the sinking export of organic matter below $Z_{\mathrm{eu}}$ and that at $150 \mathrm{~m}$. In order to directly relate POC sinking fluxes at $150 \mathrm{~m}$ with those in the traps deployed below $Z_{\text {eu }}$ (i.e. at $50 \mathrm{~m}$ ), one would have to assume POM sinking rates of $\geq 100 \mathrm{~m}$ $\mathrm{d}^{-1}$, which is on the order of the sinking velocities of fecal pellets (Lorenzen \& Welschmeyer 1983). However, the fecal pellets observed in our samples were mostly broken and highly degraded, and fecal carbon represented $<39 \%$ of the total POC sinking fluxes (Table 2). We believe that such degraded fecal material could not have sunk at velocities as high as $100 \mathrm{~m}$ $\mathrm{d}^{-1}$ during our study. Alternatively, when considering that sinking velocities of particles in the upper ocean typically range from 10 to $50 \mathrm{~m} \mathrm{~d}^{-1}$ (Sarmiento \& Gruber 2006), the particles sinking below $Z_{\text {eu }}$ would have reached the $150 \mathrm{~m}$ traps in 2 to $10 \mathrm{~d}$. A sinking velocity of $50 \mathrm{~m} \mathrm{~d}^{-1}$ would be consistent with the slight increases observed in chl $a$ and phytoplankton cell sinking fluxes at $150 \mathrm{~m}$ from Days 2 to 4 (Fig. $5 \mathrm{a}, \mathrm{C}$ ). Nevertheless, these latter increases were minimal. Therefore, although we do not exclude the existence of a potential temporal lag between primary production and the sinking fluxes of organic matter at $150 \mathrm{~m}$, we still surmise that the fairly constant POC sinking fluxes at $150 \mathrm{~m}$ were more likely related to short-term variability in POC recycling in the upper twilight zone, as explained below.

\section{Temporal variability in POC recycling in the upper twilight zone}

The e-ratios reported in the present study (20 to $86 \%$ below $\mathrm{Z}_{\text {eu }}$ and 7 to $71 \%$ at $150 \mathrm{~m}_{i}$ Fig. 4 c) compare well with values of 8 to $79 \%$ reported previously by Buesseler et al. (1992) at $75 \mathrm{~m}$ in the northeast Atlantic Ocean in springtime. Harrison et al. (1993) reported e-ratios of 26 to $38 \%$ at $150 \mathrm{~m}$ in the northwest Atlantic Ocean in springtime. According to Buesseler (1998), 
most of the open ocean is characterized by e-ratios $\leq 5-10 \%$; e-ratios $\geq 50 \%$ are the exception rather than the rule and are usually associated with spring blooms at mid-latitudes. During the decline of the bloom, the increases in the e-ratio, both below $\mathrm{Z}_{\text {eu }}$ and at $150 \mathrm{~m}$, were concomitant with the decrease in primary production (Fig. 4a,c), which translates into POC from primary producers being exported with a greater efficiency throughout this period. The increase (from $26 \%$ on Day 2 to $83 \%$ on Day 6 ) in the ratio of the POC sinking flux at $150 \mathrm{~m}$ to that below $\mathrm{Z}_{\text {eu }}$ during the decline of the bloom (Fig. 4b) also emphasizes the increase in the transfer efficiency (Buesseler et al. 2007b) of POC through the upper twilight zone during this period. On Day 20, the low e-ratios $\left(20 \%\right.$ below $Z_{\text {eu }}$ and $15 \%$ at

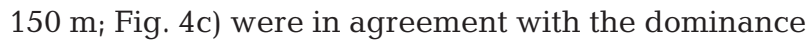
of small flagellated cells ( $\leq 5 \mu \mathrm{m}$; Pommier 2007).

The increase in the transfer efficiency of POC through the upper twilight zone during the decline of the bloom could have been related to the temporal decrease in POC recycling in the upper twilight zone, as deduced from the vertical profiles of POC sinking fluxes (Fig. 3). The decrease in POC sinking fluxes with depth is usually parameterized by the power law function of Martin et al. (1987), according to which $\mathrm{POC}_{z}=\mathrm{POC}_{100 \mathrm{~m}} \times(z / 100)^{-\mathrm{b}}$ (where $\mathrm{POC}_{z}$ and $\mathrm{POC}_{100 \mathrm{~m}}$ are the POC sinking fluxes at depth $z$ and at $100 \mathrm{~m}$, respectively, and $b$ corresponds to the slope of the power law function). In the equation of Martin et al. (1987), $b$ is a key parameter reflecting the strength of organic matter recycling with depth: the larger the value of $b$, the faster the decrease in POC sinking fluxes with depth and the higher the recycling of organic matter (Primeau 2006). Using the approach of Martin et al. (1987), the parameter $b$ was estimated for each day of our study from the slope of the regression between POC sinking fluxes and depth, after a log-log transformation of initial values. On Day 2, b was 1.24, which is in agreement with the value of 1.28 reported for the North Atlantic Ocean by Berelson (2001). On Days 4, 6 and 20, $b$ was 0.58, 0.14 and 0.49, respectively. The $b$ values from Days 4 to 20 were particularly low considering the values ranging from 0.60 to 1.28 reported by Berelson (2001) for the North Atlantic, Equatorial Pacific and Southern Oceans and the Arabian Sea. These low values indicate a low recycling of POC in the upper twilight zone from Day 4 onwards, and the temporal decrease in $b$ supports the reduction in the recycling of POC within the upper twilight zone throughout the decline of the spring bloom. The ensuing increase in the transfer efficiency of POC within the upper twilight zone could have compensated for the decrease in POC export below $\mathrm{Z}_{\text {eu }}$, thus smoothing the temporal variations in POC sinking fluxes at $150 \mathrm{~m}$ from Days 2 to 6 (Fig. 4b). Moreover, the parameter $b$ was positively correlated to the POC sinking flux below $Z_{\text {eu }}$ throughout the study period (Kendall's $\tau$ coefficient of rank correlation, $p<0.01$ ). A positive correlation between $b$ and POC export at $100 \mathrm{~m}$ has already been reported by Berelson (2001), who found that intensity of organic matter recycling in the upper $1000 \mathrm{~m}$ of the water column is related to the amount of POC exported at $100 \mathrm{~m}$. Our results are in agreement with those of Berelson (2001) and emphasize that the intensity of POC recycling within the upper twilight zone is proportional to the amount of POC exported from $\mathrm{Z}_{\mathrm{eu}}$. Many biological processes in the oceans follow a first-order kinetic, so that the rate of a reaction is proportional to the amount of material present (Boyd \& Trull 2007). In line with this, the decrease in POC exported from $\mathrm{Z}_{\text {eu }}$ from Days 2 to 6 could have induced a proportional decrease in the rate of POC recycling by the heterotrophic community within the upper twilight zone. Our results also suggest that the processes of POC recycling in the upper twilight zone responded rapidly to the variability of $\mathrm{POC}$ inputs from $\mathrm{Z}_{\text {eu }}$ as already reported by Buesseler et al. (2007b) in the northwest Pacific Ocean.

Ultimately, our study sheds light on the importance of short-term variability in POC recycling during its sinking through the upper twilight zone for the efficiency of POC export to depth. Our results also emphasize the importance of top-down control in shaping the sinking export of POC to the deep ocean over short time scales, as already reported by Wassmann (1998). Many biological interactions between the different components of the pelagic food webs can impact the sinking flux of POC, such as zooplankton grazing (including coprophagy/coprorhexy), bacterivory by heterotrophic nanoflagellates, bacterial mineralization of POC and viral lysis of phytoplankton and bacterial cells. Although we did not directly consider these factors, information about mesozooplankton grazing can be deduced from the temporal changes in phytoplankton and fecal POC sinking fluxes, as explained below.

\section{Mesozooplankton grazing in the upper twilight zone}

The consistently higher fecal carbon sinking fluxes at $150 \mathrm{~m}$ than below $\mathrm{Z}_{\text {eu }}$ throughout the study period (Fig. 6c) reflects the production of fecal pellets by mesozooplankton within the upper twilight zone. Zooplankton grazing rates were not measured during the present study. However, the mesozooplankton ingestion rate $(I)$ can be estimated from the fecal pellet sinking rate measured at $150 \mathrm{~m}(E)$, assuming an assimilation efficiency (AE) of $70 \%$ (Carlotti et al. 2000) and using the relationship $I=E /(1-\mathrm{AE})$ (Båmstedt et al. 
2000). This calculation gives potential ingestion rates of 147,87 and $177 \mathrm{mg} \mathrm{C} \mathrm{m}^{-2} \mathrm{~d}^{-1}$ by the migrating zooplankton population in the upper water column on Days 2, 4 and 6, respectively. These ingestion rates could have been underestimated due to potential coprophagy/coprorhexy by the ubiquitous small calanoid copepod Oithona similis (Reigstad et al. 2005) which was the most abundant zooplankton species in the upper $100 \mathrm{~m}$ of the water column throughout the study period (E. Head, Bedford Institute of Oceanography, pers. comm.). Considering the total particulate primary production rates of 2317, 481 and $326 \mathrm{mg} \mathrm{C}$ $\mathrm{m}^{-2} \mathrm{~d}^{-1}$ on Days 2, 4 and 6, respectively (Fig. 4a), the mesozooplankton could have ingested an increasing proportion (from 6 to $54 \%$ ) of the daily primary production during the decline of the bloom. These values are particularly high compared to previous values of $2.7 \%$ (Dam et al. 1993) and < $\%$ (Harrison et al. 1993) reported for the temperate North Atlantic Ocean during the spring phytoplankton bloom.

On Day 2, a large fraction of the sinking phytoplankton in the upper twilight zone was probably grazed by mesozooplankton. This is supported by lower sinking fluxes of chl $a$, phytoplankton cells and phytoplankton carbon at $150 \mathrm{~m}$ than below $\mathrm{Z}_{\text {eu }}$ (Figs. 5b,c \& 6a). However, from Day 4 onwards, similar sinking fluxes of phytoplankton cells and phytoplankton carbon were measured at both depths (Figs. 5c \& 6a) despite consistently higher carbon sinking fluxes of fecal pellets at $150 \mathrm{~m}$ than below $\mathrm{Z}_{\mathrm{eu}}$ (Fig. 6c). This discrepancy may reflect zooplankton vertical migrations (Ducklow et al. 2001), so that mesozooplankton grazing could have occurred at a depth different than that of defecation (e.g. grazing in $\mathrm{Z}_{\mathrm{eu}}$ and defecation in the upper twilight zone). The consistently higher carbon sinking fluxes of fecal pellets at $150 \mathrm{~m}$ than below $Z_{\text {eu }}$ despite similar sinking fluxes of phytoplankton cells and phytoplankton carbon at both depths, could also be attributed to a shift in zooplankton diet from herbivory on Day 2 to omnivory from Days 4 to 20. A shift from herbivory to omnivory has already been reported for Calanus finmarchicus under conditions of low phytoplankton standing stocks in the Gulf of St. Lawrence (Ohman \& Runge 1994). Several studies have demonstrated that the feeding behavior of calanoid copepods can be flexible enough to ingest a mixture of phytoplankton cells, microzooplankton, detritus and fecal pellets, emphasizing their omnivorous feeding behavior (Lenz 1977, Kleppel 1993). Throughout the study period, $<53 \%$ of the total POC sinking fluxes was composed of intact phytoplankton and fecal pellets (Table 2), suggesting that other sources (e.g. detrital material, marine snow, transparent exopolymers) may have made high contributions to POC sinking fluxes. Detrital material could have contributed substantially to the total POC sinking fluxes in our study, as anamorphous aggregates and degraded fecal material were observed in the particle interceptor traps. Given the abundance of detrital material and the decrease in phytoplankton sinking fluxes throughout the study period, a shift in the mesozooplankton diet from herbivory to omnivory could have occurred during the decline of the bloom, leading to a potential decrease in zooplankton grazing upon phytoplankton cells within the upper twilight zone.

The changes in the sinking fluxes of phytoplankton cells and fecal pellets provided information regarding the potential grazing pressure of mesozooplankton in the upper twilight zone. Nevertheless, more information on the composition and the functioning of the heterotrophic communities in the twilight zone is required to better constrain the decrease in POC recycling in the upper twilight zone observed during our study.

\section{CONCLUSIONS}

The present study is the first to report the relationship between primary and export production in the upper twilight zone of the temperate northwest Atlantic Ocean. POC sinking fluxes below the bottom of $Z_{\text {eu }}$ were high and progressively decreased during the decline of the bloom and its transition towards post-bloom conditions. Throughout the study period, POC sinking fluxes below $Z_{\text {eu }}$ were positively correlated to the production of large phytoplankton cells, stressing the importance of the size structure of phytoplankton communities in shaping the sinking export of POC from $Z_{\mathrm{eu}}$. However, regardless of the variability in POC export from $Z_{\mathrm{eu}}$, fairly constant POC sinking fluxes were measured at $150 \mathrm{~m}$. A positive correlation was found between the sinking flux of POC below $Z_{\text {eu }}$ and $\mathrm{POC}$ recycling within the upper twilight zone, which led to an increase in POC transfer efficiency at $150 \mathrm{~m}$ throughout the study period. It is hypothesized that the concomitant decreases in POC export from $Z_{\text {eu }}$ and in POC recycling within the upper twilight zone led to fairly invariant POC sinking fluxes at $150 \mathrm{~m}$. Our results emphasize that although the magnitude and the size structure of primary production may condition the export of POC from $\mathrm{Z}_{\text {eu }}$ these variables do not provide reliable information on the efficiency of carbon export to the deep ocean. Our results stress that the recycling processes within the upper twilight zone are very dynamic and can respond rapidly and proportionally to the variability in POC inputs from $Z_{\mathrm{eu}}$. The short-term variability in the recycling of POC within the upper twilight zone appears to be a critical factor governing the transfer efficiency of POC from $Z_{\text {eu }}$ to the deep ocean. 
Acknowledgements. This project was supported by grants from the Natural Sciences and Engineering Research Council (NSERC) of Canada and the Canadian Foundation for Climate and Atmospheric Sciences to M.G. and C.M., and by financial support from the Freshwater Institute (Fisheries and Oceans Canada) to C.M. J.P. received post-graduate scholarships from the 'Programme de bourses d'excellence pour étudiants étrangers du Fonds québécois de la recherche sur la nature et les technologies', ISMER and Québec-Océan. We gratefully acknowledge the Canadian Coast Guard officers and crew of the CCGS 'Hudson' for their invaluable support during the expedition. We are especially indebted to S. Roy and Z. P. Mei for technical assistance in the field. We also thank D. Bérubé for CHN analyses, C. Jose and É. RousselGarneau for phytoplankton cell and fecal pellet counts, E. Head and L. Harris for providing mesozooplankton data, L. Devine for revising this manuscript and 2 anonymous reviewers for their constructive and insightful comments. This is a contribution to the research programs of C-SOLAS, the Freshwater Institute (Fisheries and Oceans Canada), ISMER and Québec-Océan.

\section{LITERATURE CITED}

Angel MV (1989) Does mesopelagic biology affect the vertical flux? In: Berger WH, Smetacek VS, Wefer G (eds) Productivity in the ocean: present and past. John Wiley \& Sons, New York, p 155-173

Antia AN, Koeve W, Fischer G, Blanz T and others (2001) Basin-wide particulate carbon flux in the Atlantic Ocean: regional export patterns and potential for atmospheric $\mathrm{CO}_{2}$ sequestration. Global Biogeochem Cycles 15:845-862

Baker ET, Milburn HB, Tennant DA (1988) Field assessment of sediment trap efficiency under varying flow conditions. J Mar Res 46:573-592

Båmstedt U, Gifford DJ, Irigoien X, Atkinson A, Roman M (2000) Feeding. In: Harris RP, Wiebe $\mathrm{PH}$, Lenz J, Skjoldal HR, Huntley M (eds) ICES zooplankton methodology manual. Academic Press, San Diego, CA, p 297-399

Berelson W (2001) The flux of particulate organic carbon into the ocean interior: a comparison of four US-JGOFS regional studies. Oceanography 14:59-67

Bishop JKB (1989) Regional extremes in particulate matter composition and flux: effects on the chemistry of the ocean interior. In: Berger WH, Smetacek VS, Wefer G (eds) Productivity of the ocean: present and past. John Wiley \& Sons, New York, p 117-138

Boyd PW, Newton PP (1995) Evidence of the potential influence of planktonic community structure on the interannual variability of particulate organic carbon flux. Deep-Sea Res I 42:619-639

Boyd PW, Newton PP (1999) Does planktonic community structure determine downward particulate organic carbon flux in different oceanic provinces? Deep-Sea Res I 46:63-91

Boyd PW, Trull TW (2007) Understanding the export of biogenic particles in oceanic waters: Is there a consensus? Prog Oceanogr 72:276-312

Buesseler KO (1998) The de-coupling of production and particulate export in the surface ocean. Global Biogeochem Cycles 12:297-310

Buesseler KO, Bacon MP, Cochran JK, Livingston HD (1992) Carbon and nitrogen export during the JGOFS North Atlantic bloom experiment estimated from ${ }^{234} \mathrm{Th}:{ }^{238} \mathrm{U}$ disequilibria. Deep-Sea Res 39:1115-1137
Buesseler KO, Antia AN, Chen M, Fowler SW and others (2007a) An assessment of the use of sediment traps for estimating upper ocean particle fluxes. J Mar Res 65: $345-416$

Buesseler KO, Lamborg CH, Boyd PW, Lam PJ and others (2007b) Revisiting carbon flux through the ocean's twilight zone. Science 316:567-570

Carlotti F, Giske J, Werner F (2000) Modeling zooplankton dynamics. In: Harris RP, Wiebe PH, Lenz J, Skjoldal H, Huntley ME (eds) ICES zooplankton methodology manual. Academic Press, London, p 571-667

Caron G, Michel C, Gosselin M (2004) Seasonal contribution of phytoplankton and fecal pellets to the organic carbon sinking flux in the North Water (northern Baffin Bay). Mar Ecol Prog Ser 283:1-13

$>$ Dam HG, Miller CA, Jonasdottir SH (1993) The trophic role of mesozooplankton at $47^{\circ} \mathrm{N}, 20^{\circ} \mathrm{W}$ during the North Atlantic Bloom Experiment. Deep-Sea Res II 40:197-212

Ducklow HW, Steinberg DK, Buesseler KO (2001) Upper ocean carbon export and the biological pump. Oceanography 14:50-58

Forget MH, Fuentes-Yaco C, Sathyendranath S, Platt T, Pommier J, Devred E (2007a) Computation of primary production from remote sensing of ocean colour at the northwestern Atlantic C-SOLAS Lagrangian site. Mar Ecol Prog Ser 352:27-38

Forget MH, Sathyendranath S, Platt T, Pommier J, Vis C, Kyewalyanga MS, Hudon C (2007b) Extraction of photosynthesis-irradiance parameters from phytoplankton production data: demonstration in various aquatic systems. J Plankton Res 29:249-262

Gardner WD (2000) Sediment trap sampling in surface waters. In: Hanson RB, Ducklow HW, Field JG (eds) The changing ocean carbon cycle: a midterm synthesis of the Joint Global Ocean Flux Study. Cambridge University Press, Cambridge, p 240-281

González HE, González SR, Brummer GJA (1994) Shortterm sedimentation pattern of zooplankton, faeces and microplankton at a permanent station in the Bjørnafjorden (Norway) during April-May 1992. Mar Ecol Prog Ser 105:31-45

Gosselin M, Levasseur M, Wheeler PA, Horner RA, Booth BC (1997) New measurements of phytoplankton and ice algal production in the Arctic Ocean. Deep-Sea Res II 44:1623-1644

Harrison WG, Head EJH, Horne EPW, Irwin B and others (1993) The Western North Atlantic Bloom Experiment. Deep-Sea Res II 40:279-305

Hillebrand H, Dürselen CD, Kirschtel D, Pollinger U, Zohary $\mathrm{T}$ (1999) Biovolume calculation for pelagic and benthic microalgae. J Phycol 35:403-424

Honjo S (1996) Fluxes of particles to the interior of the open oceans. In: Ittekkot V, Shhäfer P, Honjo S, Depetris PJ (eds) Particle flux in the ocean. John Wiley \& Sons, Chichester, p 91-145

Honjo S, Manganini SJ (1993) Annual biogenic particle fluxes to the interior of the North Atlantic Ocean studied at $34^{\circ} \mathrm{N}$ $21^{\circ} \mathrm{W}$ and $48^{\circ} \mathrm{N} 21^{\circ} \mathrm{W}$. Deep-Sea Res I 40:587-607

Kähler P, Bauerfeind E (2001) Organic particles in a shallow sediment trap: substantial loss to the dissolved phase. Limnol Oceanogr 46:719-723

Kleppel GS (1993) On the feeding behaviour of calanoid copepods. Mar Ecol Prog Ser 99:183-195

Knap A, Michaels A, Close A, Ducklow H, Dickson A (1996) Protocols for the Joint Global Ocean Flux Study (JGOFS) core measurements. JGOFS Report No. 19. Reprint of the IOC Manuals and Guides No. 29, UNESCO, 1994 
Knauer G, Asper V (1989) Sediment trap technology and sampling: report of the U.S. GOFS working group. U.S. GOFS Planning Report 10

Legendre L, Le Fèvre J (1989) Hydrodynamical singularities as controls of recycled versus export production in oceans. In: Berger WH, Smetacek VS, Wefer G (eds) Productivity of the ocean: present and past. John Wiley \& Sons, New York, p 49-63

Lenz J (1977) On detritus as a food source for pelagic filterfeeders. Mar Biol 41:39-48

Lorenzen CJ, Welschmeyer NA (1983) The in situ sinking rates of herbivore fecal pellets. J Plankton Res 5:929-933

Lund JWG, Kipling C, Le Cren ED (1958) The inverted microscope method of estimating algal numbers and the statistical analysis of estimations by counting. Hydrobiologia 11: $143-170$

Martin JH, Knauer GA, Karl DM, Broenkow WW (1987) VERTEX: carbon cycling in the Northeast Pacific. Deep-Sea Res 34:267-285

Menden-Deuer S, Lessard E (2000) Carbon to volume relationships for dinoflagellates, diatoms, and other protist plankton. Limnol Oceanogr 45:568-579

Michel C, Gosselin M, Nozais C (2002) Preferential sinking export of biogenic silica during the spring and summer in the North Water Polynya (northern Baffin Bay): temperature or biological control? J Geophys Res 107:3064

Ohman MD, Runge JA (1994) Sustained fecundity when phytoplankton resources are in short supply-omnivory by Calanus finmarchicus in the Gulf of St. Lawrence. Limnol Oceanogr 39:21-36

Parsons TR, Lalli CM (1988) Comparative oceanic ecology of the plankton communities of the subarctic Atlantic and Pacific Oceans. Oceanogr Mar Biol Annu Rev 26:317-359

Parsons TR, Maita Y, Lalli CM (1984) A manual of chemical and biological methods for seawater analysis. Pergamon Press, Toronto, ON

Pommier J (2007) Variabilité de la production primaire et de l'exportation du carbone organique particulaire dans la zone mésopélagique de l'océan Atlantique nord-ouest lors du déclin d'un bloom printanier de diatomées. $\mathrm{PhD}$ dissertation, Université du Québec à Rimouski, Rimouski, QC

Primeau F (2006) On the variability of the exponent in the power law depth dependence of POC flux estimated from

Editorial responsibility: Howard Browman, Storebø, Norway sediment traps. Deep-Sea Res I 53:1335-1343

Reigstad M, Wexels Riser C, Svensen C (2005) Fate of copepod faecal pellets and the role of Oithona spp. Mar Ecol Prog Ser 304:265-270

Roux R, Gosselin M, Desrosiers G, Nozais C (2002) Effects of reduced UV radiation on a microbenthic community during a microcosm experiment. Mar Ecol Prog Ser 225:29-43

Sarmiento JL, Gruber N (2006) Ocean biogeochemical dynamics. Princeton University Press, Princeton, NJ

Smayda TJ (1970) The suspension and sinking of phytoplankton in the sea. Oceanogr Mar Biol Annu Rev 8:353-414

Throndsen J (1978) Preservation and storage. In: Sournia A (ed) Phytoplankton manual. UNESCO, Paris, p 69-74

Tréguer $\mathrm{P}$, Legendre L, Rivkin RB, Ragueneau O, Dittert N (2003) Water column biogeochemistry below the euphotic zone. In: Fasham MJR (ed) Ocean biogeochemistry: the role of the ocean carbon cycle in global change. SpringerVerlag, Berlin, p 145-156

Tremblay JÉ, Hattori H, Michel C, Ringuette $M$ and others (2006) Trophic structure and pathways of biogenic carbon flow in the eastern North Water Polynya. Prog Oceanogr 71:402-425

Urban JL, Deibel D, Schwinghamer P (1993) Seasonal variations in the densities of fecal pellets produced by Oikopleura vanhoeffeni (C. Larvacea) and Calanus finmarchicus (C. Copepoda). Mar Biol 117:607-613

Utermöhl H (1931) Neue Wege in der quantitativen Erfassung des Planktons (mit besonderer Berücksichtigung des Ultraplanktons). Verh Int Verein Theor Angew Limnol 5:567-595

Volk T, Hoffert MI (1985) Ocean carbon pumps: analysis of relative strengths and efficiencies in ocean-driven circulation atmospheric $\mathrm{CO}_{2}$ changes. In: Sundquist ET, Broecker WS (eds) The carbon cycle and atmospheric $\mathrm{CO}_{2}$ : natural variations archean to present. AGU monograph 32. American Geophysical Union, Washington, DC, p 99-110

Wassmann P (1998) Retention versus export food chains: processes controlling sinking loss from marine pelagic systems. Hydrobiologia 363:29-57

Wefer G (1989) Particle flux in the ocean: effects of episodic production. In: Berger WH, Smetacek VS, Wefer G (eds) Productivity in the ocean: present and past. John Wiley \& Sons, New York, p 139-154

Submitted: March 1, 2007; Accepted: October 22, 2007 Proofs received from author(s): March 7, 2008 